\title{
Præsten og Loke
}

\section{Grundtvigs apologetiske dialog i "Om Christendommens Sandhed"}

\section{Af Troels Nørager}

Grundtvigs apologetik har ikke hidtil fået den opmærksomhed, som den fortjener. I denne artikel foretages en relativt tekstnær gennemgang af dialogen fra 1826 mellem præsten og Loke, der optræder som repræsentant for datidens "rationalistiske" teologi. De centrale temaer er knyttet til Apostolicum og afspejler således den forudgående "mageløse opdagelse" (1825). I analysen og drøftelsen af Grundtvigs apologetiske strategi fokuseres især på hans gennemgående brug af modsigelsens grundsætning. Det påvises i den forbindelse som stærkt problematisk, at Grundtvig synes overbevist om at kunne benytte dette filosofiske (formallogiske) princip til at understotte sit eksklusivt teologiske sandhedsbegreb.

I det, der kan betegnes som et af Grundtvigs religionsfilosofiske hovedværker, "Om Christendommens Sandhed", indgår en apologetisk dialog mellem en fortaler for kristendommen ("Præsten") og en anfægter af den ("Loke"). 'Denne del af teksten fylder godt 40 sider, så der er tale om mere end blot en parentes. Dertil kommer, at dialogen berører stort set alle de centrale emner i Grundtvigs teologi. På den baggrund kan det undre, at hidtidig forskning enten blot nævner dia$\operatorname{logen} \mathrm{i}$ forbifarten eller nøjes med en kort og kursorisk behandling. Det er synd, ikke blot fordi dens form og indhold kan lære os meget om Grundtvig, men også fordi en sådan dialog må påkalde sig interesse $\mathrm{i}$ en nutid, hvor teologer må forsvare kristendommen over for ateistiske kritikere. Denne artikels perspektiv er således systematisk og ikke historisk. Hensigten er at analysere dialogen relativt tekstnært for derefter afsluttende at vurdere dens argumentation.

\footnotetext{
${ }^{1}$ Dialogen trykkes som 4. og 5. Stykke af afhandlingen "Om Christendommens Sandhed" i henholdsvis oktober- og decemberheftet af Theologisk Maanedsskrift, 1826 (optrykt herfra i US IV, 590-605 og 613-641). Et optryk af hele afhandlingen sammen med afhandlingen "Om den sande Christendom", 1826, udkom i 1865 som en selvstændig bog (under begge afhandlingstitlerne som "en Tvilling-Nød") med en "Efterskrift" af Grundtvig (optrykt i US IV, 724-733).
} 


\section{Dialogens baggrund og form}

Med sin åndelige krise, der finder en løsning i omvendelsen (1810-11) til det, nutidens kirkelige højrefløj ynder at kalde for klassisk kristendom, praktiserer Grundtvig i en længere periode en bogstavelig tolkning af Bibelen. Han er dog alt for belæst og begavet til at blive stående ved en sådan opfattelse, som er blevet umuliggjort af den moderne teologis historiske bibelkritik. Med sit betydelige behov for noget sikkert at holde sig til plages Grundtvig dog hårdt af denne situation, og hans lettelse er derfor tilsvarende stor, da han endelig i 1825 gør sin "mageløse opdagelse", som indebærer, at han billedlig talt trækker sig tilbage til koret (jf. US IV, 418) og holder sig til kirken og dens ældgamle apostoliske trosbekendelse. Uanset dette vigtige teologiske kursskifte er det dog nok så væsentligt at notere sig, at Grundtvig hele sit liv bekender sig til "gammeldags kristendom" eller "Luther og fædrene" og insisterer på at betegne sig selv som gammeldags troende.

Det er således ikke overraskende, at man med god ret kan betegne hovedparten af Grundtvigs forfatterskab som apologetisk, fordi han netop tager på sig at forsvare en i mange henseender før-moderne kristendomsopfattelse. En følge heraf er, at Grundtvig i 1810'erne og 1820 'erne ser sig omgivet af modstandere til alle sider. Dem kalder han hyppigt simpelthen for "Fienden", eller lidt mere specifikt for "Rationalisterne" og "rationalistiske Theologer" (jf. US IV, 459, 474, 481 og 497). I hvor høj grad forskningen har overtaget Grundtvigs selvforståelse på dette centrale punkt, kan ses deraf, at man som oftest sammenfatter denne fase i Grundtvigs liv under overskriften "kampen mod rationalisterne". Den reelle åndshistoriske (og teologiske) kontekst turde dog være en del mere kompliceret. Vel spiller fornuften stadig en central rolle, men den primære, intellektuelle inspiration fra Tyskland er jo dog tysk idealisme og romantik, der begge er kendetegnet ved netop at vende sig imod rationalismen. ${ }^{2}$

Hvorom alting er: Med sine Verdenskrøniker (især den fra 1812) og sine pjecer i striden med H.C. Ørsted (1814) lykkes det Grundtvig

\footnotetext{
${ }^{2}$ I sin artikel om Grundtvig og rationalisterne i årene 1825-32 når Jens Rasmussen da også frem til en mere nuanceret konklusion: "I hele opgøret med sine modstandere - ikke mindst Clausenfamilien - betegnede Grundtvig tidens ledende teologer og præster som "Rationalister", hvilket var for unuanceret, og det kom til at spærre for andres forståelse af hans egentlige ærinde." (jf. Rasmussen 1998, 111). I en nylig artikel om "Grundtvig og rationalisterne" giver Jens Glebe-Møller dog Grundtvig medhold i, at datidens teologi (og især prædiken) var rationalistisk; til gengæld viser han, at Grundtvig på flere væsentlige punkter selv synes at have overtaget elementer af den rationalistiske teologi (jf. Glebe-Møller 2011).
} 
at gøre sig totalt umulig og blive anset som fanatiker og fornuftshader af den intellektuelle elite, som han ellers så gerne ville anerkendes af. Så i den henseende er der al mulig grund til at beundre hans uforfærdede kamp for sin gammeldags tro. Og så bombastisk var hans fremfærd, at selv nogle af hans nærmeste venner brød med ham. ${ }^{3}$ I begyndelsen af 1820'erne oplever Grundtvig situationen på den måde, at de intellektuelle er blevet trætte af at strides med ham og har forladt valpladsen. Han arbejder derfor intenst med et forsvarsskrift for kristendommen, som han håber, atter engang vil kunne bringe "en Smule Rørelse i det døde Hav" (US IV, 244), men han kan, som han i samme forbindelse udtrykker det, ikke blive tilfreds med formen. I Grundtvigregistranten kan man følge disse mange udkast, der ender med at blive til det publicerede dobbeltværk, som viser os Grundtvigs besvarelse af de to centrale spørgsmål: Hvor finder man den ægte kristendom? ("Om den sande Christendom”) - og, når først dette spørgsmål er besvaret, derpå: Hvordan kan man argumentere for denne kristendoms sandhed? ("Om Christendommens Sandhed"). Hvad nu selve formen angår, er valget af dialogen ikke tilfældigt, og den dukker da også op i nogle af udkastene til det færdige arbejde. Grundtvig kan være blevet inspireret til dialog-formen fra $\mathrm{i}$ hvert fald to af de filosofiske værker, han som ung (under Langeland-tiden) læste med stor begejstring: F. W. J. Schellings dialog Bruno (1802) og J. G. Fichtes Die Bestimmung des Menschen (1800). I sidstnævnte indgår en art platonisk dialog mellem et jeg og en ånd ("der Geist"). Til forskel fra disse mulige inspirationskilder er der dog ikke meget sokratisk over dialogen mellem præsten og Loke. Den har i stedet karakter af en stridssamtale, hvor det vigtige er, hvem der vinder eller får det sidste ord. Den afgørende inspiration kommer imidlertid fra Grundtvigs beskæftigelse med antikkens kristne

${ }^{3}$ At kampen havde sin pris, fremgår også af en bevægende, selvbiografisk notits fra 1814, hvor Grundtvig skriver følgende om omvendelsens konsekvenser: "Nu blev Bibelen min Bog, og nu var ikke Talen hos mig om at læmpe den efter dette eller hint System, men at se, hvad der stod, tro og forkynde. Hvor haard Skolen var, hvori jeg maatte lære, hvad Forskiel der er paa at tro Noget af ganske Hjerte og at give det sit Bifald, hvad det kostede, inden jeg fandt mig i at lade Naade i alle Maader gaae for Ret og at forkaste al den Aandelighed, der ei kan bestaae hos Skriftens Aand, det vedkommer egenlig Ingen; men jeg berører det kun, for at Man skal indsee, hvor ligegyldig jeg maa være ved alle Beskyldninger for Intolerance, Selvtillid, Bogstavtrældom etc. Jeg veed, hvor jeg krympede mig, før jeg vilde holde op at tro mig selv, før jeg vilde dømme og tale som Guds Ord." (VU I, 100 f.). 
apologeter: Irenæus, som han med begejstring læste fra 1823, og Justinus Martyr, som han i teksten eksplicit nævner som et forbillede. ${ }^{4}$

Dialogen kaldes af begge parter for "en videnskabelig Samtale" (bl.a. US IV, 636). Den ene rolle, "Præsten", turde være et pålideligt talerør for Grundtvig selv, svarende til hans selvforståelse som "boglærd Mand" (jf. US IV , 590). At modparten kaldes for "Loke", kan næppe undre: Loke er Grundtvig særdeles velkendt fra den intense beskæftigelse med Nordens mytologi, og da han både er en trickster-figur og repræsenterer ondskab og satanisk fristelse, forekommer han nærmest perfekt til rollen som præstens modstander. Til formen hører også, at præsten og Loke driller, til dels håner, hinanden og derfor benytter sig af ironi og humoristisk-satirisk karikatur.

\section{Første del af dialogen}

Dialogen falder i to hoveddele med en pause imellem. Denne struktur giver dels Grundtvig mulighed for at indskyde nogle kommentarer efter den første runde af meningsudveksling, dels skaber den en form for suspense hos læseren: Vil det lykkes for Loke at "afbevise" (US IV, 589) trosbekendelsen, eller må han ende med at strække våben? Den reelle grund til opdelingen $\mathrm{i}$ to halvdele er dog såre pragmatisk: Grundtvig var ikke just en ordknap herre, og dialogen er undervejs vokset så meget $\mathrm{i}$ omfang, at det har været nødvendigt at fordele den på to forskellige numre af Theologisk Maanedsskrift.

\section{Dialogens indledning: fra fornuft til sandhed}

Dialogens formål er ifølge Grundtvig at besvare de vigtigste filosofiske indvendinger mod kristentroen. Grundtvig mener i den forbindelse, at både "Billighed" og "Klogskab" kræver, "at vi, under enhver Tvist om Troens Sandhed, lade det staae ved sit Værd, om den er philosophisk rimelig eller ikke, og indskrænke os til Paastanden om dens philosophiske Forsvarlighed" (US IV, 607-608). Grundtvig siger videre, at skønt han selv finder alle de såkaldte beviser mod kristendommen dårlige og lidet overbevisende, er det samme jo ikke nødvendigvis tilfældet med hans med-kristne. Vi må derfor slutte, at der i realiteten er to forskellige adressater eller målgrupper for dialogens forsvar for troen og trosbekendelsen: På den ene side de oplyste medkristne, hvis mulige anfægtelser han føler et præsteligt ansvar for bringe til ro; og på den anden side de egentlige rationalistiske modstan-

\footnotetext{
${ }^{4}$ Af Justinus Martyr er således overleveret en dialog med en jøde ved navn Tryfon; sammenlignet med Grundtvigs dialog er Justinus' dog langt mere fredsommelig, ja nærmest venskabelig i tonen.
} 
dere, som Loke repræsenterer - og som Grundtvig åbenbart stadig nærer et håb om at kunne overbevise. Denne baggrund, samt motivet for valg af dialogformen, fremgår af følgende citat, som danner optakt til den egentlige dialog:

Uagtet jeg derfor finder alle de saakaldte Beviser mod den christelige Troes Sandhed, som er kommet mig for Øren, saa ynkelige, at en boglærd Mand knap kan være bekjendt at nævne dem, saa veed jeg dog, det er, desværre, ingenlunde Tilfældet med alle mine Med-Christne, og førend jeg derfor udvikler, hvorledes Kirken giver den christelige Tro, og Historien Kirken et ligesaa priseligt som mageløst Vidnesbyrd, maa jeg bekvemme mig til at svare paa de saakaldte philosophiske Indvendinger imod Christendommen, for at gjøre det i Øine faldende, at det kun er af Armod paa Grunde, Fjenden stræber at gjøre sig vittig paa Herrens og vores Bekostning, naar han skal bevise, at det kan umuelig være sandt, og maa altsaa nødvendig være Løgn, hvad de Christne troe, og hvorpaa de bygge deres Saligheds-Haab. Dette tænker jeg, gaaer naturligst til, naar jeg vælger den dialogiske Form, der er saa gammel i Apologiens Historie, som Christendommens første i Literaturen berømte Apologet, Justinus Martyr selv, og Fjenden vil jeg kalde Loke (US IV, 590).

Dialogen tager afsæt i fornuften, idet Loke indleder dialogen med følgende fanfare: "Hvem vover at udæske Fornuftens Tilbedere, ja Fornuften selv, til at afbevise de Christnes Over-Tro, der gjendriver sig selv, og har alt længe, selv for halvvoxne Drenge, været til Spot?” (US IV, 590). Grundtvig opnår med udtrykket "Fornuftens Tilbedere" indirekte at få gjort sine rationalistiske modstandere til noget nær en religiøs sekt. Præsten svarer ved at sige, at det er selve den kristelige kirke eller dens tjenere på vegne af Herren og menigheden. Han svarer altså ikke kun på egne vegne, men som én, der er sig bevidst at have hele kirken og traditionen i ryggen. Umiddelbart efter er det præsten, der er i udfordrerens rolle, og først med lidt ironi og drilleri: "du er altsaa ikke kommet for at føre det længe belovede unægtelige Beviis mod Sandheden af den christelige Tro, men kun for at vise din Styrke i Ordspil" (US IV, 590).

Det er nu karakteristisk for den første vending, dialogen tager, at præsten af al magt vil føre diskussionen fra temaet fornuft til et spørgsmål om Sandheden: "Har du maaskee dine Grunde, hvorfor du heller vil tale om vor Troes Forhold til Fornuften, som Ingen rigtig veed, hvad er, end om dens Forhold til Sandheden, som Alle veed, hvad er, eller har vi maaskee hidtil misforstaaet dig, saa du egenlig slet ikke vil nægte, at det muelig kan være sandt, hvad vi troe, men at du blot, efter din Tanke-Gang, finder det urimeligt?" (US IV, 591). Vi mindes her om distinktionen mellem "Rimelighed" og "Forsvarlighed": kun det sidste vil præsten forholde sig til, og her gælder det for ham om, 
hvilket vi allerede kan ane på dette tidspunkt, at den kristne tro - som sammenfattet i trosbekendelsen - kan være mulig sandhed. I denne forbindelse forekommer det dristigt at hævde, at alle ved, hvad sandhed er; men påstanden hænger sammen med Grundtvigs klippefaste tillid til modsigelsens grundsætning. ${ }^{5}$

Det andet, vi kan hæfte os ved, er, at Grundtvig lader præsten benytte en strategi, som han selv anvender flittigt, nemlig at gøre fornuften usikker ved at pege på, hvor omstridt og uklart dens begreb er. Denne form for fornuftskritik videreføres i præstens næste indlæg: "i mine Øine er der saaledes ingen urimeligere Ting til, end en Fornuft, der ikke begriber sig selv, vil gjøre Alt, hvad den ikke begriber, til Løgn, og dog gjøre sit eget ubegribelige Selv til Sandhed" (US IV, 591). ${ }^{6}$

At det er lykkedes præsten at få samtalen drejet fra fornuft til sandhed, viser sig nu derved, at Loke indfører det berømte Pilatus-spørgsmål: hvad er Sandhed? Præsten svarer i første omgang med en karakteristik, der svarer til en klassisk opfattelse af sandhed som korrespondens: "eller synes dig ikke, at naar man udsiger, hvad man virkelig finder, da siger man Sandhed, og finder den, naar man finder Tingen, som den er?" (US IV, 591). Præstens næste skridt består nu i at optræde som den, der har retten til at definere stridens kerne; han formulerer det som en udfordring til Loke, der nu - i markant forskel til dialogens start - står som den, der har bevisbyrden:

Kort og godt altsaa: kan du bevise, at det er Løgn, hvad de Christne bekjende Tro paa, som urokkelig, saliggjørende Sandhed, saa gjør det; og kan du det ikke, men kalder kun vor Tro en slem, løgnagtig OverTro, fordi den ikke vil rime sig med din ubegribelige Fornuft, saa tilstaae, at det kommer an paa en Prøve, kun de Troende kan gjøre, om vor Tro er sand og saliggjørende, eller ikke! (US IV, 592)

\footnotetext{
${ }^{5}$ Modsigelsens grundsætning (principium contradictionis) går ud på, at en dom (et udsagn om noget i verden) ikke både kan være sand og falsk. Udsagnet 'A er ikke-A' er således paradigmet på enhver falsk dom. Modsigelsens grundsætning er kernen i det, Grundtvig også kan henvise til som "Tanke-Lovene" eller "Tænkningens uforanderlige Principer" (jf. fx US IV, 403).

${ }^{6}$ Grundtvigs fornuftskritik er et centralt tema, som dog desværre falder uden for denne artikels rammer. Det følgende citat fra Kirkens Gienmoele viser dog, at Grundtvig har skabelsesteologiske grunde til ikke blot at ville give afkald på fornuften: "Vil de hedde Rationalister, velan! vi kan vist nok ikke fraskrive os Fornuften, enten som den er i Gud, eller som den billedlig er i os, men vi have Intet at bramme af, og overlade derfor gierne vore Modstandere det pralende Navn, ligesom Kirke-Fædrene, uden at forpligte sig til Dumhed, overlod deres Modstandere Navn af Gnostiker!' (US IV, 419).
} 


\section{Trosbekendelsen}

Som var han en af Grundtvig styret marionetdukke, opfordrer Loke nu præsten til at komme ind på sin "christelige Troes-Bekjendelse, som jeg da nok kan vide, er sat anderledes paa Skruer, end de hellige athanasianske Fædres!" (US IV, 592). Man ser både heraf og senere, at Loke ikke er uden en vis teologisk viden. Hvad der imidlertid er afgørende (set fra Grundtvigs synsvinkel) er, at vi nu ikke blot er kommet fra fornuft til sandhed, men til det for Grundtvig efter 1825 centrale, nemlig at den kristne kirke ikke har andet at stå til regnskab for end trosbekendelsen ved dåben.

Præsten svarer først med en undren over, at Loke ikke kender den kristne kirkes trosbekendelse (skønt konteksten tyder på, at det gør han nu nok); det svarer jo til "at beleire en Stad, man ikke veed, hvor ligger" (US IV, 592). ${ }^{7}$ Loke udfordrer nu videre ved at minde om, hvordan "Moder Kirken" i tidens løb har haft utallige, forskellige udlægninger (via sine store teologer) og siger så til præsten: "Jeg tænkde, du var klog nok til ogsaa at lægge din søde Moder Ordene i Munden, som de, efter den nærværende Tids Pinagtighed, maatte føies, for at klinge taalelig" (US IV, 592). Med andre ord: han frister præsten til at omtolke eller tillempe trosbekendelsen til tidens smag. Men som en sand troens stridsmand holder præsten naturligvis fast $\mathrm{i}$ trosbekendelsen, som den lyder ved dåben, idet han samtidig broderer videre på metaforen "kirken er en moder":

Du behager at skjemte, eller du maa aldrig have hørt, hvad Kirken, ved sin Dør-Tarskel, forlanger af alle dem, der vil gaae ind, og hvile sig i hendes Skjød, opammes ved hendes Bryst, og oplæres i hendes FriSkole! (...) eller kjender du meer end een Troes-Bekjendelse, som Kirken udgiver for Apostolisk, altsaa for oprindelig, og uforanderlig i det Samfund, der jo altid skal have samme Tro og samme Daab? (US IV, $592 \mathrm{f}$.).

Lokes svar, der også antyder den indimellem næsten Holbergske komediestil, ${ }^{8}$ viser, at han nu forventer sig en let sejr:

\footnotetext{
${ }^{7}$ Krigsmetaforik optræder med påfaldende hyppighed i Grundtvigs skrifter og udgør i sig selv et indicium på den betydelige rolle, som den polemiske apologetik spiller.

${ }^{8}$ I Danne-Virke-afhandlingen "Om Mennesket i Verden" kommenterer Grundtvig sin stil på følgende måde: "Endnu er der een Ting, jeg ved denne Leilighed finder det passende, med et Par Ord at omtale, det Spøgende nemlig i Udtryk og Vendinger, som ikke sjelden synes at herske i min Tale om saare alvorlige Ting, noget der i det mindste har stødt Adskillige af mine kiæreste Læsere. Jeg vil begynde med den Tilstaaelse at Spøgen høist rimelig kommer stundom til Utide, thi naturam pelle furca ex, hun kommer dog igien, den Hex,
} 
Nei, det er for galt! havde jeg troet, du var saa langt tilbage i Oplysningen, da havde jeg neppe indladt mig med dig! Den stakkels gamle, forældede, fattige Bekjendelse, der saa godt som ingen Ting siger, fik allerede sin Afsked paa det Nicæniske Concilium, blev gjort umyndig af Morten Luther, og fik kun Naadsens-Brød med hans lille Catechismus hos Rollinger i Puge-Skolen, den indbilder du dig virkelig, kan gjælde for Kirkens Grund-Bekjendelse, og taale en philosophisk Undersøgelse; med den vil du indrømme, den christelige Kirke staaer og falder! Nei, saa let en Seier kan jeg ikke være bekjendt at vinde; mod Børn blotter ingen ærlig Kæmpe Sværd, og gaaer den christelige Kirke nu saaledes i Barndom, at den har glemt sin Bog, og mindes kun, hvad den lallede i Vuggen, da var det Synd at forstyrre den i sine søde Drømme, der spaae sandfærdig om et saligt Endeligt (US IV, 593).

Men præsten holder fast: "Den Sag er klar, at den Tro, vi som Christne bekjende, det er vor christelige Tro, og hvem der vil bestride den, maa holde sig til vores Bekjendelse, da han ellers paadigter os en Tro, som han naturligviis til Verdens Ende kan bestride og overvinde, uden at det paa mindste Maade rører end sige rokker den christelige Tro, vi bekjende" (US IV,593). Loke svarer drillende: hvor er du poetisk, "du bringer vel snart et Ægteskab istand mellem Mathematiken og Poesien" (US IV, 594). Og herpå kommer et svar fra præsten, som er interessant, fordi det synes at afspejle en dobbelthed såvel i Grundtvigs personlighed som i hans apologetiske projekt:

Du siger Noget, sandere vist, end du tænker; thi var vor Herre end ikke den Tømmer-Mands Søn, som boede i Nazareth, saa er Han, der lagde Blomster-Gulvet og Stjerne-Loftet, dog ogsaa en Slags Tømmer-Mand, eller Architect, i hvis Konst Poesien og Mathematiken venlig række hinanden Haand (...), saa jeg kan slet ikke finde det urimeligt, at Troen paa Christus kan gjenfødes i et poetisk Hjerte, og forsvares med betænksom Koldsindighed (US IV, 594).

Præsten vil nu holde fast $\mathrm{i}$ det, der for ham er det afgørende stridspunkt, og han udbeder sig "et bestemt Svar paa mit bestemte Spørgsmaal: om den christelige Tro, du saa ilde fortaler og erklærer for falsk og intetsigende, om det er en, som kun var til i gamle Dage, og som Ingen meer vil være bekjendt, eller det er den, vi alle vedkjende os, saamange som ved Daaben gjøre den apostoliske Troes-Bekjendelse til vores?" (US IV, 594). Og han øger presset på Loke yderligere: "Vil du

og, naar man engang faaer Øinene op, skal man vel see, at min Natur er saa langt fra alt Fantasterie, at den snarere er alt for prosaisk tør og tam, og uden i øvrigt paa nogen Maade at sammenligne mig med Holberg, tør jeg tillægge mig samme naturlige Smag for Poesie, Sværmerie og alt Sligt som han, hvorfor ogsaa han til mit 23de Aar var mit Mønster paa en virkelig Poet og en fuldkommen Skribent." (Grundtvig 1983, 36). 
tilstaae, at denne christelige Tro, som vor Bekjendelse udtrykker, ei indeholder det Mindste, som du med din Philosophie kan gjøre til Løgn"? (US IV, 594).

Loke prøver nu på at komme væk fra trosbekendelsen igen og siger: "Lad os dog heller tale om Bibelen, som et Guds Ord; det er dog et videnskabeligt Spørgsmaal, man kan være bekjendt at drøfte (...): rimeligviis er Bibelen en Bog som alle andre Bøger, men muelig kan den dog ogsaa være en Bog over alle Bøger!" (US IV, 595). Præsten svarer, at Bibelens guddommelighed til verdens ende vil være et tvistens æble, og "saa er vi jo ligefuldt uenige om den christelige Tro, som jeg bekjender og du fornægter; og om den ikke ogsaa nok muelig kan medføre Sandhed, det er Spørgsmaalet, som vor Tale skal dreje sig om, og som du kun forgjæves vil snoe dig fra" (US IV, 595). ${ }^{9}$

I det følgende kommer de to ordstridere nærmere ind på bekendelsens indhold, og præsten foreslår, at de straks tager fat på det, der formentlig er den største anstødssten, nemlig Kristi nedfart til Helvede. For som han siger: "der er vist Intet, du troer klarere at kunne afbevise, og har du først afbeviist den, da forlanger jeg ikke meer, men rækker dig strax Broder-Haand som U-Christen" (US IV, 596). Det samme løfte om overgivelse fremsættes også senere, og vi kan heraf udlede, hvad der for Grundtvig står på spil: Hvis blot ét enkelt element $\mathrm{i}$ trosbekendelsen kan påvises at stride mod "unægtelig Sandhed" (US IV, 603; jf. modsigelsens grundsætning), falder det hele. Denne alt eller intet-tænkning er i det hele taget karakteristisk for Grundtvigs apologetik.

Loke mener, at dette er så langt ude, at præsten må være blevet vanvittig "og maa, ved din Doctor-Disputats om Nedfarten til Helvede som Christendommens Hoved-Sag, have dine beskikkede Opponenter fra Daare-Kisten!" (US IV, 596). - Som man ser, er dialogen ikke uden indslag af humor. Præsten svarer, at han "efter Tænkningens ubøielige Grund-Lov, erklærer den christelige Tro for falsk, naar den i Lidt eller Meget er Tro paa Løgn" (US IV, 596). Med udtrykket "Tænkningens ubøielige Grund-Lov" (hyppigt forekommende i Grundtvigs

${ }^{9}$ Jf. også følgende udtalelse fra præsten: "Dit Smil siger mig, det er ikke noget Nyt, jeg her fortæller dig; du veed det godt, at den Tro, vor Bekjendelse udtrykker, er den eneste christelige Tro, som har været dig til Anstød, og holdt Stand, i Morten Luthers Bryst og Tale saavelsom i Polycarps, og nægt derfor kun ikke, det var en videnskabelig Helte-Gjerning, der maatte gjøre dig udødelig, ja, reise dig et Guddoms-Tempel paa Christi Kirkes Gruus, dersom du kunde soleklart bevise, at der var Løgn i den Tro, vor apostoliske Bekjendelse udtrykker" (US IV, 595). 
skrifter) tænkes der på modsigelsens grundsætning og den deraf følgende skarpe dualisme mellem sandhed og løgn, sandt og falsk. ${ }^{10}$

\section{Helvede, opstandelse og himmelfart}

Loke vejrer morgenluft, da spørgsmålet om Helvede og Kristi nedfart til dødsriget (det, vi på nudansk nok ville kalde for en tabersag) er kommet på dagsordenen, og han mener, at de nu snart må kunne blive enige, "thi du maa jo dog indrømme, at naar der intet Helvede er til, kan heller Ingen fare derned" (US IV, 597). Men ligesom for en sikkerheds skyld spørger han, hvad helvede er, og hvor det i grunden ligger? Præsten besvarer spørgsmålet på følgende måde:

At Helvede paa Dansk, saavelsom Hades paa Græsk, er de Dødes Rige, det veed du vel, men vil du vide, hvor det ligger, da siig mig først, hvor Sjcelen ligger i Legemet, og naar vi da har gode Stunder, kan vi snakke om, hvor den ligger udenfor Legemet, naar vi er døde; men du seer nok, det kommer ikke Troen ved, som kun gaaer ud paa, at Christi Sjæl, medens hans Legeme laae i Graven, gjæstede Sjælene af andre Afdøde, og mener du virkelig, det var umueligt? (US IV, 597).

Det er værd at bemærke, at præsten faktisk ikke besvarer spørgsmålet om Helvede, men i stedet taler mere alment om de dødes rige, og det er samtidig tankevækkende, at han slår over i en (kristendommen fremmed) græsk sjæ1/legeme-dualisme. Og i præstens næste replik slås det ligefrem fast, "at Christi Død virkelig var en Skilsmisse mellem Sjael og Legeme, og at altsaa den selvgjorte Christus, der kun skal være daanet, for at spille Gjenganger, slet ikke er den Christus, paa hvem vi troe og bygge vort Saligheds-Haab!" (US IV, 597).

Loke ser kløgtigt i præstens skarpe adskillelse mellem sjæl og legeme en mulighed for en indvending, idet han peger på, at "jo dødere han [Kristus] var, des vissere mener jeg dog, det er, at han stod aldrig op igjen, og at han, hvis Sjæl foer til Helvede, endnu mindre baade med Sjæl og Krop foer til Himmels! Dog, du er maaskee fin nok til ogsaa at lade Opstandelsen og Himmelfarten være blot aandelig?" (US IV, 597f.). Præsten opdager dog den fælde, der hermed er sat for ham, og fastholder opstandelsen og himmelfarten - med såvel sjæl som legeme: "At den Korsfæstede i figurlig Forstand brød Dødens Lænker og opsvang sig til Himmelen (...), see, det er en Kjends-Gjerning, som

${ }^{10}$ Det må dog ikke overses, at den via modsigelsens grundsætning udprægede dualisme i Grundtvigs kristendomstænkning primært er influeret af teologien i Grundtvigs yndlingsevangelium, Johannesevangeliet. Man gør formentlig ret i at udlægge sagen på den måde, at Grundtvigs forkærlighed for modsigelsens grundsætning er begrundet $i$, at han her mener at have fundet et filosofisk værktøj, der kan stå i teologiens tjeneste. 
ingen Spotter og ingen Anti-Christ kan nægte" (US IV, 598). Opstandelsen er for præsten en kendsgerning, fordi den er bekræftet af "ØienVidner". Tilbage står dog den inkonsekvens (som Loke dog ikke forfølger), at det kun var Kristi sjael, der besøgte Dødsriget, hvorimod opstandelsen var "figurlig" (her i betydningen: i menneskeskikkelse). Præsten konkluderer nu af Lokes reaktion (eller mangel på samme), "at du ligesaalidt kan afbevise Christi legemlige Opstandelse og HimmelFart, som hans aandelige Nedfart til Helvede, og at altsaa Alt uden Undtagelse, hvad vi troende bekjende om Jesus Christus, kan muelig vare sandt!" (US IV, 598). Præsten synes altså foreløbig at have opnået, hvad han ville.

Loke replicerer dog med en, forekommer det, vigtig pointe; han spørger nemlig nu præsten, hvad det skulle nytte, at alt det urimelige kunne være sandt, "naar jeg ligefuldt, med uomstødelige Grunde, beviser, det er ikke sandt", hvorefter han skærper tonen:

Er du virkelig saa dum, at du ikke kan begribe saa simpel en Ting, eller er du et fortvivlet Stykke af en Poet, som vil nøde Erfaringen til at realisere dine sværmeriske Drømme, eller er du endelig en lumpen Hykler, som selv ikke troer et Ord af, hvad du med Kirken bekjender, men vil kun prøve, om man dog ikke endnu en Gang, til Kirkens og hendes Sønners Bedste, kunde tage Menneske-Fornuften fangen under KulsvierTroens Lydighed (US IV, 599).

Dette citat er interessant af mindst to grunde: for det første, fordi det endnu engang antyder en spænding i Grundtvigs egen identitet mellem på den ene side poeten med de sværmeriske drømme og på den anden side den polemisk-filosofiske logiker. Og for det andet, fordi det netop er Grundtvigs gentagne motto eller program efter omvendelsen, at fornuften skal tages fangen under troens lydighed. ${ }^{11}$

Præsten fortsætter nu i logikerens rolle med sin yndlingspointe baseret på modsigelsens grundsætning: "saa tør du jo dog ikke nægte, at Alt, hvad der ikke lader sig afbevise, det kan vare sandt, og kan altsaa muelig troes, skjøndt det tykkes sært, netop af udmærket SandhedsKjærlighed og den fine Følelse for, hvad sandt er, som deraf nødvendig følger!” (US IV, 599). Men, må man spørge, har vi ikke her at gøre med sandhed i en helt anden betydning? Talen om "Sandheds-Kjærlighed" synes i det mindste at trække i en mere voluntaristisk retning.

Og præsten maser videre på: "Kan du nu hverken bevise, at Noget af dette i sig selv er Løgn, eller at det Ene strider mod det Andet, saa

"Jf. således allerede "Fortale til Nytaarsnat" (1810), hvor Grundtvig i et tilbageblik på sin åndelige krise skriver: "Det faldt mig endnu stedse for tungt at tage Fornuften fangen under Troens Lydighed, jeg vilde selv udgrunde hvorfor Kristendommen var sand" (VU I, 325). 
det Hele umuelig kan være sandt; kan du ikke det, saa lad kun ikke, som du blot af Føielighed indrømmer, hvad du ei, uden at giøre dig selv til Løgner, kan nægte: Mueligheden af vor Christendoms Sandhed" (US IV, 600). Loke giver dog ikke op endnu, men stiller i stedet det frække spørgsmål om, hvor i Himlen Kristus befinder sig, når han nu er faret legemlig derop? Der skal dog mere til at vælte præsten, som imidlertid går ind på spørgsmålets præmis (at Kristus må være reelt og synligt til stede et sted i universet), samtidig med at han kommer med et overraskende løsningsforslag:

Ja saa! Du trøster dig altsaa, ligesom hin berømte vantro Astronom, dermed, at man endnu ikke, selv med de bedste Kikkerter, har seet vor Herre enten i Maanen eller i Stjernerne; men hvad om han nu sad i Solen, der unægtelig har saamegen Del i de Guds Gjerninger, Verden seer, at den, efter verdslig Viisdom, vel maa agtes for at være nær ved Guds høire Haand, see, saa var der jo en tilstrækkelig Grund, baade til at man ikke saae vor Herre i Maanen eller paa Melke-Veien, og til at man slet ikke saae ham, før man fik en Kikkert, hvori man kunne gjennemskue Solen! (...) eller kan du virkelig bevise, at den legemlige Himmelfart er Løgn, naar vi ikke med geographisk Nøiagtighed kan betegne de himmelske Boliger? Ja eller Nei! (US IV, 600).

\section{Jomfrufødslen}

Et af de oftest angrebne led i trosbekendelsen er utvivlsomt jomfrufødslen, så det er ikke underligt, at Loke bringer dette emne op. Præsten viger dog ikke fra sin apologetiske strategi, som samtidig er et konstant modangreb: bevis, at det er en umulighed! Præsten: "Du vover altsaa at kalde Herrens Undfangelse og Fødsel uden jordisk Fader en Umuelighed, og der fattes altsaa kun Beviset; da er vi enige om at vende Kirken Ryggen" (US IV, 601). Loke svarer, at han vil være "føielig nok til at indrømme, at man kan lade den Sag, det er anstødeligt at røre ved, staae ved sit Værd, især da de første Capitler hos Matthæus og Lucas, hvorpaa jo dog det Hele beroer, kan muelig være uægte" (US IV, 601). Men præsten agter ikke at give indrømmelser til den historiske bibelkritik; i stedet svarer han med en formulering, der antyder, hvilke fordele Grundtvig har set ved at gå fra det lutherske princip om at udlede troen af Skriften - og til koncentrationen omkring trosbekendelsen:

[T]hi du veed ligesaa godt som jeg, og har selv nys sagt det, at naar blot vi frafalder den Paastand, at Jesus kom til Verden paa en overnaturlig Maade, da kunde du bevise, at vor øvrige Bekjendelse om ham var et sig selv modsigende Æventyr, og det var desaarsag meget klogt af Fjenden, da man vilde udlede Troen af Skriften, at vække Tvivl om Ægtheden af Herrens Fødsels-Historie, men det er ogsaa klogt af os, aldrig, for nogen Priis, at adskille, hvad Herren i vor Troes-Bekjendelse 
har sammenføiet, og hvad der hænger saa guddommelig sammen, at ingen Djævel formaaer at sønderrive Kjæden (US IV, 601). ${ }^{12}$

\section{Første trosartikel: Gud som Skaber}

Loke bringer gudstanken op ved at tale om "de mere fromme end forsvarlige Begreber om en Gud, der er saaledes over Naturen, at han kan forandre dens Love, som en Konge sine Forordninger, og saaledes Verdens Skaber, at han har gjort Alting af Intet eller af en ubekvem Materie, som I pleier ret morsomt at beskrive, hvad intet fornuftigt Menneske kan tænke Noget ved" (US IV, 602). Præsten svarer ved at tale om Gud som skaber på en lidt anden måde, nemlig som "en levende Gud, hvis aandelige Kraft alt Andet, baade Aandeligt og Legemligt, skylder sin Tilværelse" (US IV, 602). Det lyder i nutidige øren ganske moderne, men umiddelbart efter (hvor det endnu engang er blevet præsten, der kaster en handske til Loke) lyder det atter ganske traditionelt: "siig mig blot, om du trøster dig til at bevise, at den alraadende Gud Fader, Himmelens og Jordens Skaber, som er LivsRoden i de Christnes Tro, at Han ikke er til!" (US IV, 602). Loke replicerer ved at spille bolden tilbage: "Du maa jo dog selv tilstaae, at en saadan Guds Tilværelse er ubeviislig" (US IV, 602). Præsten reagerer herpå med følgende svar:

Nei, skjøndt jeg hverken er Doctor i Philosophien eller Theologien, vilde jeg dog skamme mig ved at sige den Dumhed, at Noget i Verden var beviisligere end Skaberens Tilværelse; men hvad kommer det for Resten denne Sag ved? de Christne sige jo ikke, de kan føre et videnskabeligt Beviis for Tilværelsen af deres og al Verdens Skaber, men at de troe paa Ham, og det har de jo unægtelig Lov til, med mindre du kan bevise, enten at Hans Tilværelse er umuelig, altsaa utroelig, eller at den alraadende Gud ei er værd at troe paa. Altsaa, beviis, eller tilstaae, at hverken vor første eller anden Troes-Artikel indeholder eller forudsætter Noget, som jo muelig kan være sandt, skjøndt du ikke troer det! (US IV, 602f.; jf. en tilsvarende formulering vedrørende syndsforladelsen, US IV, 604).

Det mærkelige her er, at Grundtvig i første omgang (med rette) henviser til den kvalitative forskel mellem tro og videnskabeligt bevis, men kun for i anden omgang at afkræve Loke et bevis for umuligheden af Guds eksistens. Det hænger ikke just godt sammen.

12 Jf. hertil også det sted tidligere i "Om Christendommens Sandhed", hvor Grundtvig triumferende beskriver, hvordan han ved et "Lykke-Træf" fandt trosbekendelsen: det "levende, høirøstede Vidnesbyrd om, hvad der er den sande Christendom, som har den besynderlige Egenskab, at Modstanderne, som vil hedde Christne, ei kan modsige det, uden klarlig at modsige sig selv, hvilket, som bekjendt, er den unægtelige Sandheds usvigelige Kjende-Mærke!" (US IV, 523). 


\section{Tredje trosartikel}

Som flere gange antydet er det karakteristisk for Grundtvigs apologetiske dialog, at præsten hele tiden skubber bevisbyrden over på Loke. Det gælder også drøftelsen af 3. trosartikel, som præsten introducerer med denne konstatering: "Hidindtil har dog de Verdslig-Vise fundet det for vanskeligt [at modbevise dens indhold], og nøiedes med at paastaae, at disse Ting ikke lod sig bevise, saa, dersom du kan bevise, de lade sig ikke engang troe, uden at trodse en unægtelig Sandhed, da maa du have fundet de Vises Steen" (US IV, 603). Citatet er endnu et eksempel på den uklare sammenblanding af tro og bevisførelse, som netop blev påpeget.

Loke strammer nu tonen og kommer med en præste-kritik, der vækker mindelser om Voltaire: "I Nat-Ugler, som misbruger den Smule Forstand, I har, til at besmykke Dumhed, og indbilde Folk, at Mørket, som I seer jeres Fordeel ved, er det vel dunkle, men velgjørende, og Alt $\mathrm{i}$ en salig Evighed forklarende Lys, der ved eder opgaaer for dem, som sidde i Dødens Skygge, og kjøbes ingenlunde for dyrt med Opoffrelse af kjødelig Fornuft, og alt Kjødeligt, som ikkun Præster uden Synd kan bruge" (US IV, 604). Præsten replicerer (som modspil til "Nat-Uglen"), at han "hører til et Samfund, hvis Lyst det er at svare til det store Navn af Lysets og af Dagens Børn", og derfor er det ham "naturligviis magtpaaliggende, at det kan blive klart, baade for Venner og Fjender, at den Christelige Kirke har Intet at dølge, Intet at frygte, og kun Mørkets Rige at bestride" (US IV, 605).

\section{Dialogen afbrydes}

Præsten og Loke har nu krydset klinger om alle tre artikler i trosbekendelsen. Dialogen er dog langtfra færdig. Præsten er foreløbig godt tilfreds med situationen og mener, at Loke (ved af egen drift at nævne opstandelsen) har "indrømmet Mueligheden af alle vore TroesSætninger" (US IV, 604), og han er ligefrem så kæk, at han opfordrer Loke til under en pause at finde på flere og nye indvendinger.

Mens de to opdigtede samtalende hviler ud, benytter Grundtvig lejligheden til at tage ordet på egne vegne med en længere betragtning, hvis indhold der er grund til at se nærmere på:

Selv for en af de hedenske Mythologier vilde det være en stor Triumph, hvis det maatte indrømmes, at den hverken laa i Strid med sig selv eller med nogen unægtelig Sandhed; thi vel var dermed dens Forestillingers Sandhed ingenlunde beviist, men den kunde dog gjøre sikker Regning paa hos alle Sandheds Venner at have Formodningen for sig (...). At vi derfor ligesaalidt kiende nogen Mythologie, som noget philosophisk System, der i Eet og Alt lader sig forsvare, er en mærkværdig [bemar- 
kelsesvardig] Ting, som kan gjøre os Nødvendigheden af en overordentlig Aabenbaring anskuelig; men her vil vi dvæle ved den Sandhed, at det for Christendommen endnu er en langt større Triumph, end det kunde være for nogen Mythologie, naar man nødes til at indrømme, at den slet Intet indeholder, som jo ${ }^{13}$ muelig kan være sandt; thi Christendommen har et historisk Vidnesbyrd om sin Troeværdighed, som sund Fornuft maa erklære for fuld-gyldigt, naar der kun Intet findes, som er aldeles utroeligt, fordi det strider mod unægtelig Sandhed, og derfor ikke ved nogetsomhelst Vidnesbyrd kunde blive troværdigt (US IV, 605f.).

Man kan af dette ræsonnement fra Grundtvig selv udlede følgende tre påstande eller tankegange, idet vi lægger mærke til, at han - hvilket må betragtes som fejlagtigt - vil anvende ens grundsætning på religioner eller livsanskuelser, og ikke kun på domme eller udsagn. ${ }^{14}$ Grundtvig begynder for det første med at fastslå, at en religion, der ikke umiddelbart ligger i strid med sig selv eller med en efter modsigelsens grundsætning unægtelig sandhed, ikke dermed har bevist sine "Forestillingers" sandhed. Det betyder blot det mere beskedne, at den pågældende religion har "Formodningen" (US IV, 605) for sig. - Men det er lidt vagt; hvad skal vi forstå ved det? At den er en værdig kandidat til prædikatet "Sandhed"? (US IV, 605). Dernæst siger Grundtvig videre: Jeg kender ingen religion eller noget filosofisk system, som i ét og alt lader sig forsvare (betyder "forsvare" her at kunne holde til modsigelsens grundsætning-testen?), og han slutter deraf til "Nødvendigheden af en overordentlig Aabenbaring" (US IV, 606). Nødvendig hvorfor og for hvem? Vil han hermed antyde, at der må være givet mennesker en absolut sandhed, og at denne ene, sande Sandhed kun findes i kristendommen, fordi det kun er her, at Sandhedens Gud har meddelt sig? Grundtvig hævder i det citerede endelig (her som i øvrigt i sine skrifter), at kristendommen er "sand" $\mathrm{i}$ en dobbelt henseende: modsigelsens grundsætning viser, at den intet indeholder, som umuligt kan være sandt, og den har historiens "Vidnesbyrd om sin Troeværdighed, som sund Fornuft maa erklære for fuld-gyldigt" (US IV, 606).

\footnotetext{
${ }^{13}$ På ældre dansk og endnu i det 19. århundrede betyder et "jo", som står i en sætning efter en forudgående sætning med en nægtelse i, "ikke".

${ }^{14}$ Erik Kelstrup har da også vist, at nutidig filosofi (repræsenteret af Tugendhat og Strawson) "ikke forstår modsigelsens grundsætning som en ontologisk lov", men at der i stedet er tale om "så at sige et indre sprogligt anliggende" (Kelstrup 2000,135). Denne vigtige ændring går dog helt tilbage til Kant, hvorfor Kelstrup også kan notere det som "ganske evident, at hos Kant, Tugendhat og Strawson afvises modsigelsens grundsætning som en ontologisk lov" (136). Det giver Kelstrup visse problemer (som dog ikke skal forfølges her), eftersom han - noget modvilligt - må erkende, at "Grundtvig flere gange brugte den [modsigelsens grundscetning] ontologisk" (137).
} 
Blot to bemærkninger til det sidste punkt: Det er fint, at Grundtvig med prædikatet "Troeværdighed" markerer, at historiens vidnesbyrd har en anden filosofisk status end den "Sandhed", som kan tillægges de domme, der ikke forbryder sig mod modsigelsens grundsætning. Og endelig kunne man lidt drilsk være fristet til at ironisere over, at når Grundtvig skal kritisere "Rationalisterne", kan han tale længe om, at ingen ved, hvad fornuft er for noget; men når det drejer sig om "sund Fornuft" (som han ofte selv påkalder sig), véd han pludselig godt, hvad dét er for noget.

Og kort efter kaster Grundtvig sig netop ud i en kritik af kristendommens fjender i det 18. århundrede, hvorefter han fortsætter:

[T]hi det lader sig unægtelig bevise, og er derfor en guddommelig Vished i ethvert sandhedskjærligt Hjerte, at hverken kan en Tro, hvori der findes mindste Gran af Vildfarelse, være guddommelig sand, ikke heller kan Gud gjøre Løgn til Sandhed, fordi Han derved nægtede og tilintetgjorde sig selv. Derfor, og derfor ene og alene, er det, vi maae føre den, i Øvrigt ufrugtbare, Tvist med Christendommens Fjender om Umueligheden i philosophisk at afbevise den (US IV, 606).

Fremhævelsen, som er Grundtvigs, er vigtig, og endnu vigtigere bliver den af at stå side om side med den nøgterne erkendelse af, at striden med kristendommens fjender ikke fører til noget. Grundtvig dermed mere end antyder, at dialogen mellem præsten og Loke er spild af både tid, papir, pen og blæk! Så hvorfor dog? Fremhævelsen giver svaret: Det hele er i virkeligheden til internt brug; striden skal føres udelukkende for gudstankens skyld, det vil sige: fordi Gud som Sandhedens Gud ikke kan modsige sig selv.

Uagtet at Grundtvig netop har erklæret striden for ufrugtbar, vil vi dog alligevel følge den til ende. Og lad os tage fat et sted, der knytter sig direkte til den netop omtalte problematik. Det findes i en sammenhæng, hvor han finder anledning til at prise den oldkirkelige skriftfortolkning, "saaledes som den især tiltaler mig igjennem Irencus" - og lidt senere understreger han så: "Vor Tro kan ikke være Sandheds-Tro, uden at være ligesaa uforanderlig som Sandhed selv" (US IV, 612). Altså: Sandheden må evig og altid være den samme. Det kan man jo godt acceptere, når det gælder formallogisk sandhed (modsigelsens grundsætning), eller korrespondenssandhed, men gælder det også i trosanliggender? Det mener Grundtvig. Det er dog vigtigt at være opmærksom på, at han i denne forbindelse skelner mellem tro og teologi. Til forskel fra den uforanderlige tro må vor teologi hele tiden vokse uden dog i denne verden nogen sinde at nå til at blive "fuldvoxen", som det udtrykkes. Grundtvig uddyber synspunktet ved at minde læserne om sin egen nylige opgivelse af det lutherske skriftprincip til fordel for koncentrationen om trosbekendelsen: 
[J]eg takker Gud, fordi han har oplyst mig til at indsee og rette mine theologiske Feiltagelser, og jeg har det velgrundede Haab, at, bliver jeg tyve Aar ældre, skal jeg ogsaa voxe til en høiere Klarhed og en fastere Ligevægt, uden at vige et Haarsbred fra den uforanderlige christne Tro og Bekiendelse, som umuelig kunde være Sandhed, hvis vi ikke befæstedes deri, ved ethvert Fremskridt i Sandheds Erkjendelse (US IV, 612).

Som kommentar til citatet kan anføres, at hvis Grundtvig har levet op til sit løfte om ikke at "vige et Haarsbred" etc., hvad der er sandsynligt nok, tyder det vel i retning af en grundlæggende kontinuitet snarere end på brud i Grundtvigs tænkning? Eller rettere, hvis vi benytter den anførte sondring: at hans tro grundlæggende forbliver den samme, hvorimod hans teologi præges af accentforskydninger. Men kan man i det hele taget opretholde en så skarp distinktion mellem tro og teologi? Og kan Grundtvig? Det forekommer tvivlsomt.

\section{Anden del af dialogen}

Loke er i pausen åbenbart kommet på bedre tanker og genåbner nu debatten med en venlig indrømmelse til kristendommen, "hvori jeg erkjender et stort, guddommeligt Opdragelses-Middel for MenneskeSlægten, hvis underfulde Oprindelse vel er mig en besynderlig Gaade, man ei skulde forkjættre Nogen for, men hvis Virkninger, under Forsynets Styrelse, have været saa velgjørende, at de vel kunde fortjene at henføres til den vidunderligste Aarsag, og berettige til den barnligste Tro!" (US IV, 613). Det lyder jo i sig selv smukt, men Loke erkender desuden, at han under forste del af samtalen "kan have sagt Adskilligt", som ikke lader sig filosofisk forsvare. Som en slags forklaring på sin opførsel siger han, at han "agtede kun at laane Spotterens usømmelige Mine, for at vise dig, hvilken Miskjendelse Christendommen udsattes for, naar man lagde uforholdsmæssig Vægt paa dens historiske, vidunderlige Side" (US IV, 613). ${ }^{15}$ I øvrigt mener han, at han er blevet misforstået af præsten, og han foreslår, at de mødes i en fælles erkendelse af, at de begge i kampens hede "tabde den Ligevægt, Besindighed og Skaansel, der bør være uadskillelige fra en Samtale om saa dybe og vanskelige Ting" (US IV, 614). Men efter så megen selvransagelse føler han sig berettiget til at afkræve præsten en indrømmelse, nemlig "at i Grunden er det dog Religionens moralske

\footnotetext{
${ }^{15}$ Formuleringen er interessant, fordi den antyder, at den historiske bibelkritiks afvisning af at fundere troen på NTs mirakler er båret af en intention, der senere genfindes i Bultmanns afmytologiseringsprogram.
} 
Virkninger, der godtgjøre Dens Guddommelighed, og afkræve os dyb Ærbødighed, selv hvor vi maae tvivle" (US IV, 614). ${ }^{16}$

\section{Barnedåben og forsagelsen}

Loke bedyrer generelt sin dybe ærbødighed for "Kirkens NaadeMidler" (US IV, 614), men mener, at der i tidens løb uundgåeligt har blandet sig noget menneskeligt ind i det, og at det derfor burde ombyttes med noget nyt, der "renere og bedre udtrykde og befordrede de store aandelige Øiemed for hele den kirkelige Virksomhed", og han må i den forbindelse "tilstaae, at Barne-Daaben, under sin nærværende Indretning, med Djoevle-Forsagelse, Troes-Bekjendelse og SyndsForladelse, har saameget Upassende, Unyttigt og Urimeligt ved sig, at det ligesaa lidt bør undre dig som mig, at det synes Mange Gjøgleværk, og hartad Alle en barnagtig forældet Kirke-Skik, som trængde høit til Forandring!" (US IV, 615). At det især er barnedåben, der er en anstødssten, fremgår lidt senere, hvor han erklærer, at "uden at ville nægte, at Endeel af det Anstødelige bortfalder, naar det er en Voxen, der, efter foregaaende Underviisning, og med velberaad Hug, lader sig døbe, maa jeg dog, Sandheden til Ære, bekjende, at intet samtidighedsfuldt og oplyst Menneske, naar Alt skal tages saa strængt, som du selv fordrer, kan troende eftersige og annamme, hvad I ved Daaben kræve og tilsige; men jeg lader gjerne den Undskyldning gjælde, at det er tvivlsomt, hvorvidt Daaben er indrettet ganske efter Christi Villie" (US IV, 616).

Denne tilsyneladende venlighed får dog blot præsten til skarpt at præcisere, at hvis ikke dåben forrettes "i alle Maader efter Christi Indstiftelse (...) da ere vi falske Christne o: Kjættere" (US IV, 616 f.). Loke replicerer ved at tale om præstens "ubillige Strænghed mod dit eget Samfund, der saalidt som Noget, menneskelige Vilkaar undergivet, kan være feilfrit!" (US IV, 617). - Det forekommer vel at være en ganske god pointe, men den bringer for alvor modparten i harnisk. For præsten (og ligeledes for Grundtvig) er det alt eller intet, enteneller:

See, du blev da Kirkens inderligste Ven, der i Grunden elskede den over alle Ting, selv over Sandhed, og vi, med vor overdrevne Iver for Sandhed og Oplysning, ja vi blev da, som man siger, Kirkens og Christi Korses Fjender; men seer du vel, under disse Betingelser er vor Samtale ude; thi hører du til de fortvivlede Tvivlere, der lade unoegtelig Sandhed

\footnotetext{
${ }^{16}$ Det er vigtigt at være opmærksom på, at den teologiske position, Loke her repræsenterer, er tidstypisk. Man genfinder den $\mathrm{fx}$ i toneangivende dele af amerikansk teologi (unitarismen) fra omkring 1820, hvor Göttinger-skolens historiske bibelkritik vinder indpas. Jf. hertil Dorrien 2001, kap. 1.
} 
staae ved sit Værd, som noget Tvivlsomt, da lønner det aabenbar ikke Umagen at skifte Ord med et Utyske, hvis hele Tilværelse, altsaa ogsaa hans Tvivlraadighed, maa være ham tvivlsom, og som da i Grunden slet ikke veed, om han siger eller hører Noget, eller ikke. Altsaa, høistærede Hr. Sextus Empiricus ${ }^{17}$ den Yngste! Et af To: enten er vor Samtale ude, eller du indrømmer, uden al Forbeholdenhed, at hvem der erklærer sig imod vor Daab, erklærer sig derved imod vor Kirke, og maa da enten kunne afbevise dens Christelighed, eller finde sig i at behandles som den christelige Kirkes erklærede Fjende (US IV, 617).

Loke kommenterer (i og for sig ganske rammende) denne svada ved at tale om præstens "logiske Sværmeri" og "umaadelige Hidsighed" (US IV, 618). Og endelig kommer han så med det enten-eller (vedrørende dåbens uforsvarlighed), som præsten har afkrævet ham, og derfor siger han: "Er du nu fornøiet!” Præsten svarer på følgende måde:

Som man kan være fornøiet paa en Valplads, hvor, som Morten Luther kvæder: Livet og Døden de føre en underlig Strid om, hvem der skal tages af Dage, ja, saa fornøiet er jeg virkelig ved denne din Erklæring, det har holdt saa hardt at udpine af dig (...) Kom nu kun frem med dine Indvendinger mod vor Daab, og glæd dig, naar jeg gjendriver dem; thi derved redder jeg dig øiensynlig, saavidt du kan reddes, fra Døden, i hvis Arme du stokblind har kastet dig! (US IV, 618).

Det viser sig nu, at Loke har tre kritiske spørgsmål vedrørende dåben: "Om det er forsvarligt, høitideligt at besværge Tilværelsen af en Person, som ikke er til? Om det er forsvarligt, høitideligt at love Folk Salighed for, hvad der umuelig kan gjøre Nogen salig? Og endelig, om det er forsvarligt, at erklære et Troes-Samfund for et Guds Rige, hvis Medlemmer ei engang forpligtes til Nidkjærhed i Dydens Udøvelse?" (US IV, 618). Vi ser altså her, som ovenfor, hvordan det på god rationalistisk-deistisk vis er vigtigt for Loke dels at fastholde en begrundelsessammenhæng $\mathrm{i}$ forholdet mellem moral og religion, dels at insistere på, at det religiøse sindelag må manifestere sig i en moralsk praksis.

Hvad de rejste spørgsmål angår, afslår præsten naturligvis at bevise Djævelens eksistens og opfordrer i stedet Loke til at komme med et bevis på, at der aldrig har været en Djævel til. Og lidt senere tilføjer han: "og glem for Alting over din Lystighed ikke det strænge Beviis, du unægtelig skylder Kirken for, at den, ved at forudsœtte Djævelens Tilværelse, forudsætter Noget, som ei kan være, altsaa heller ikke er til!" (US IV, 619). Loke spørger nu, hvad Djævelen i grunden er? Djævelen er, erklærer præsten, "Grund-Løgneren" (vi aner her atter det teologiske behov for modsigelsens grundsætning), og han tilføjer: "Or-

${ }^{17}$ Græsk filosof ca. 200, der var læge og teorifjendsk empiriker; hans filosofiske værker er en hovedkilde til viden om antik skepticisme. 
det Djoevel har for den Ulærde ved Daaben ingen anden Mening, end en, aandelig talt, personlig Fjende ad den christelige Tro og det christelige Liv, hvem alle Christne skal erklære Krig og undflye alt Samfund med" (US IV, 619 f.).

Det fremgår således indirekte af præstens svar til Loke, at han sætter lighedstegn mellem "Christi og Sandhedens Fjende". Han følger tankegangen til dørs med en anklage mod Loke: "hvorfor betænkde du ikke, at du, ved at nægte Tilværelsen af den Djaevel, Kirken undsiger, i alt Fald aandelig tilintetgjorde dig selv; eller kan du ikke dog nok forstaae, at $e r d u$, aandelig talt, Noget, da har jo Kirken i det mindste $i$ dig en Djaevel, hvem den, for at bestaae, nødvendig maa forsage, med alle hans Gjerninger og alt hans Væsen!" (US IV, 620). - Og lidt senere igen hedder det uddybende, at kirken "blot vilde gjøre dig det paa en fornuftig Maade indlysende, at, saalænge den christelige Tro og Kirke aandelig bestrides [bekcempes] af en Person, saalænge har de, og Christus i dem, unægtelig en Grund-Fjende o: en Djoevel, som skal undsiges, og som deres nærværende Modstandere maae finde sig i selv at udgjøre, naar de nægte Tilværelsen af Kirkens Grund-Fjende i en høiere Orden" (US IV, 621).

\section{Sandhedsspørgsmålet endnu engang}

Loke stiller nu et i hele sammenhængen afgørende spørgsmål: "indrømmer du maaskee, at der er en væsenlig Forskjel mellem Kirkens og Sandhedens Grund-Fjende?" (US IV, 621). Dette spørgsmål făr straks præsten op på barrikaderne:

Spørger du mig virkelig, om jeg ikke nok foreløbig vil indrømme, at Christendom er Løgn, som den jo maatte være, naar Christus ikke var den lyslevende Sandhed i egen guddommelige Person (...), da paaligger dig Beviset for, enten at Sandhed ingen Grund-Fjende har, eller at Sandhedens og Kirkens Grund-Fjende dog ikke er een og den Samme! Hvilken af Delene trøster du dig nu til videnskabelig strængt at bevise? (US IV, $621)$.

Det synes, som om præsten her reelt erklærer, at det sandhedsbegreb, hvorom hele dialogen drejer sig, er eksklusivt teologisk. Men hvorfor så med vold og magt spænde det op i modsigelsens grundsætnings formallogiske prokrustesseng? Det skaber jo kun uklarhed og unødig forvirring, blandt andet fordi det teologiske sandhedsbegreb tydeligvis anvendes i ontologisk øjemed, hvorimod modsigelsens grundsætning vedrører epistemologiens gebet.

Loke prøver nu på at bløde det hele lidt op ved at sige, at al bestridelse af sandhed skyldes manglende indsigt, men det afvises netop på det skarpeste af præsten: 
Nei, ikke saa! reen Fod at gaae saavelsom at staae paa! Reiser virkelig, $i$ Grunden, al Strid mod Sandhed sig af Forblindelse og Misforstand, da er ikke alene Christendommen forkastelig, men al vor Tale om aandelig Sandhed latterlig; thi har Gud ikke havt mere Kjærlighed til Sandhed, end at han skabde Løgn til dens Plage, da er det jo latterligt, at vi vil være mere sandhedskjærlige end vor Skaber (US IV, 621).

Loke prøver at forsvare sig: "Naar har jeg sagt, at Sandhed og Løgn er i Grunden Eet og det Samme?" (US IV, 622). Herpå svarer præsten ved endnu engang at betone sin skarpe dualisme:

Enten ere de dog vel $i$ Grunden Eet og det Samme, eller to med hinanden i al Evighed uforenelige Ting af modsat Oprindelse, og du maa jo da enten paastaae, at der er, i Grunden, ingen Løgn eller vitterlig Sandheds-Fornægtelse (er) til, eller at Gud er i Grunden ligesaavel Løgnens som Sandhedens Fader og Grundaarsag, og hvilket vælger du nu? (US IV, 622).

Loke prøver på dette sted i samtalen at holde fast i sit tidligere kritiske spørgsmål, nemlig om ikke kirken i højere grad burde forpligte sine medlemmer på "et dydigt Levnet" (US IV, 623). Men præsten holder fast $\mathrm{i}$ dåben $\mathrm{og}$ trosbekendelsen - kun det har kirken at forsvare. Loke applicerer derefter sin indvending på de døbtes mindre end dadelfri vandel:

Jeg mener, at de saakaldte Gjenfødtes aabenbare Vandring i det gamle Skind er Beviis nok for, at Vandet ei kan udrette saa store Ting, som jo selv Morten Luther indrømmer, og i Øvrigt fattes der dog ved Daaben unægtelig den høitidelige Forpligtelse til Moralitet, som maa kræves i Sandhedens Troes-Samfund, ligesom ogsaa Troen tillægges en Trolddoms-Kraft, den, som en blot Mening, umuelig kan have (US IV, 622).

Men præsten viger ikke fra sit yndlingstema: "det er Sagen, at naar du ikke kan afbevise vor nødvendige Paastand, at Kirkens og Sandhedens Fjende er een og den Samme, da sværge vi aabenbar, ved at forsage Djævelen (...) høitidelig til Sandheds Banner, og hvem der uindskrænket hylder og følger Sandhed, uden al Forbindelse med Løgn og Ondskab, er dog vel moralsk" (US IV, 624). Det er fra præstens side den eneste form for svar, vi făr på spørgsmålet om sammenhængen mellem tro og moral.

Loke spørger nu, om kirken har opgivet sine "Grund-Dogmer", hvilket får præsten til at indføre en vigtig distinktion, som indikerer (hvad Grundtvig også andre steder gør til en pointe), at med den kirkelige anskuelse er Skriften og dogmatikken blevet overladt til teologernes indbyrdes strid:

Theologien har Dogmer (Lære-Sætninger), men Kirken har ingen, uden forsaavidt den har en theologisk Høi-Skole; i sig selv har Kirken, som et Troes-Samfund, og et aandeligt Guds Huus, kun Tro og Haab og Kjær- 
lighed, med dertil svarende Naade-Midler, og staaer kun til Regnskab for, hvad den i Troes-Bekjendelsen og ved Naade-Midlernes Brug levende udtrykker. (...) Hold dig derfor her smukt til, hvad du kan bevise, Kirken vedkjender sig, og afgjør Resten med Theologerne, om du kan lokke eller true dem til at disputere med dig om Skriften og Dogmatiken! (...) med de theologiske Gjætninger eller Grublerier, om det indbyrdes Forhold i den os ubegribelige Guddom, har Kirken Intet at giøre (US IV, 624f.).

Loke spørger tilbage: "Altsaa forkaster du den Athanasianske, og sagtens tillige den Nicæniske Troes-Bekjendelse?" Præsten: "det er jo soleklart, at enten skal enhver Christens Troes-Bekjendelse aldeles sammensmelte med Kirkens Almindelige og Oprindelige, eller ogsaa det er aldeles en Privat-Sag (...). Enten er der altsaa slet ikke mere i den Athanasianske og Nicæniske, end i den Apostoliske Bekjendelse, eller ogsaa det mere er Kirken uvedkommende" (US IV, 626). Præsten omtaler dem et par gange som "Privat-Bekjendelser" og slutter sit indlæg med at slå fast, at alle sådanne er, "som det sig bør, henlagde til de kirkehistoriske Acter, hvor de er paa deres rette Hylde" (US IV, 626).

Loke er dog ikke slået helt af banen endnu og indvender: "Jeg mener dog, at saavel den Augsburgske Confession, som Danske Lov lærer noget ganske Andet?" (US IV, 626). Og her er faktisk et af de få steder $\mathrm{i}$ hele dialogen, hvor det er tydeligt, at præsten kommer lidt $\mathrm{i}$ forlegenhed. Han får sig dog samlet til følgende svar: "kan du ikke dog nok begribe, at en Christen har slet Intet med en Stats Lære-Forskrifter at gjøre, med mindre han vil være Lærer [prcest] i Statens Tjeneste (...) Hvor enten geistlig eller verdslig Øvrighed har taget sig den Frihed at gjøre deres egne Meninger til Troes-Artikler, der er den christelige Kirke kun modsigende tilstæde" (US IV, 626).

\section{Andre temaer}

Dialogens absolut dominerende emne er (helt efter Grundtvigs ønske) trosbekendelsen. I sidste del af samtalen kommer dog også andre temaer ind i billedet, således fx temaet forsoning og retfardiggørelse. Det rummer unægtelig komplicerede spørgsmål, men præsten drager her god nytte af sin sondring mellem tro og teologi, der indebærer, at han kun skal stå til regnskab for, hvad kirken siger. Han replicerer derfor til Loke: "siig mig nu, om du har hørt Kirken i denne Henseende fordre mere af de Christne end Tro paa det Christi Ord, at Han hengav sit Legeme for dem, og udøste sit Blod til deres Synders Forladelse, eller om det er disse Ords Sandhed, du tiltroer dig at kunne afbevise?'(US IV, 630). Men den snedige Loke ved jo, at kirken har sine bekendelsesskrifter og - i det mindste i denne forstand - også en teologi. Derfor maser han på: "Du tør altsaa ikke forsvare den 
evangelisk-lutherske Kirkes Grund-Lærdom om Fyldestgjørelsen [ $\mathrm{s} a$ tisfaktionsteorien] og den indbyrdes Tilregnelse mellem Frelseren og hans Troende?" (US IV, 630). Præsten er dog ikke til sinds at opgive sin bekvemme arbejdsdeling mellem tro og teologi, kirke og skole:

Hvor tit skal jeg sige dig, at Loerdom og Lore-Scetninger har hjemme i Skolen og ei i Kirken! Er du virkelig saa tykhovedet, at du ikke kan begribe, at hvad Kirken siger, det siger den til Alle, og det maa kunne fattes eens af Alle, da det skal troes til et evigt Liv; men at hvad der udvikles i Skolen, det udvikles for dem, der kan nemme det, til timelig Oplysning og stykkeviis Erkjendelse, uden at Nogen bliver derfor enten bedre eller slettere Christen (...) Gaverne ere forskjellige, men Aanden er den samme: een Herre, een Tro, een Daab, een Gud og alles Fader, som er i, og med, og over Alle! (US IV, 630 f.).

Loke er, som det følgende citat viser, ikke tilfreds med dette svar:

Slidder-Sladder tilhobe, eller bliver ikke dog Meningen, saavel i Kirken som i Skolen, at I Christne faaer Synds-Forladelse, ikke fordi I forbedre jer, men fordi jeres Frelser lod sig korsfæste, og at I blive salige, ikke fordi I ved et dydigt Levnet har gjort jer værdige til Lyksalighed, men ene og alene fordi det skal behage Faderen at gjøre dem salige, som troe paa den Korsfæstedes igjen Opstandnes Navn, og er dette dog ikke ligesaa oprørende i moralsk som i philosophisk Henseende? (US IV, 631f.).

Han fremsætter nu i tilknytning hertil den opfattelse, at synd ikke er andet "end en nødvendig Følge af Sandselighedens Overvægt over Fornuften" (US IV, 632). Præsten svarer på denne måde:

Nei, det forstaaer sig selv; kan du bevise, at Gud er i Grunden den eneste Synder, som Han nødvendig maatte være, naar han havde skabt os saaledes, at vi nødvendig maatte synde, da er det naturligviis ikke os, men Ham, der trænger til Synds-Forladelse, og da er Christendommen afbeviist; men da Synd nu kun er, hvad der strider mod Guds Villie, og Gud umuelig kan fristes til at stride mod sig selv, eller tage for godt, hvad der strider mod Hans Villie, saa turde den Paastand være en Smule latterlig, og gik i Grunden ud paa, at Gud var en Djævel, og Himmerig et Helvede, hvor den indvortes Strid, som er vor Plage, ret egenlig havde hjemme (US IV, 632).

På dette tidspunkt dukker så nadveren op til diskussion. Dette tema indledes med et drillende-ironisk indlæg fra Loke, som går i rette med den lutherske lære om realproesens:

Kun ikke saa fornem, min umaadelig strænge Logiker, som dog ikke tager i Betænkning, paa den hellige Kirkes Vegne, at erklære Brødet for Kjød, og Vinen for Blod, og et Legeme for allestedsnærværende, hvad, efter min ringe Forstand, dog forudsætter et temmelig venligt Forbund mellem Bekræftelsen og Benægtelsen af eet og det samme, 
altsaa, efter din egen plumpe Tale-Brug: mellem Sandhed og Løgn; eller er du maaske, med al din lutherske Orthodoxi, dog i Grunden Krypto-Kalvinist! (US IV, 633).

Vi ser her et eksempel på, at Loke forsøger at vende modsigelsens grundsætning, præstens primære våben, mod ham selv. Præsten bider dog ikke på krogen, men anfører i stedet, at indstiftelsesordenes ordlyd går tilbage til Jesus selv:

Men du maa jo dog indrømme, at, har Jesus virkelig brugt de Ord, vi ved Nadveren i Hans Navn gjentage, da maatte de enten være Løgn i Hans Mund, eller kan i Kirken, som Hans Mund, endnu være sande, og at altsaa den Jesus Christus, hvis Stiftelse den christelige Kirke er, enten virkelig kan gjøre sine Troende, ved Brødet og Vinen, deelagtige i sit Legeme og Blod, eller ogsaa han er en Bedrager, som ingenlunde maa overøses med Lovtaler! (US IV, 633).

Hertil replicerer Loke:

Det er ikke min Sag; thi naar jeg berømmer Jesus Christus, da forudsætter jeg naturligviis, at han var et guddommelig fornuftigt Menneske, der umuelig kunde paastaae noget aabenbar Ufornuftigt og Selvmodsigende, saa at enten har han ikke sagt, hvad Kirken lægger ham i Munden, eller ogsaa har han meent noget ganske Andet dermed (US IV, 633).

Præsten holder endnu en gang karakteristisk fast i kirken - og ikke i Skriften: "Ja saa! hvoraf, maa jeg spørge, uden af den christelige Kirke, kjender du da Jesus Christus, siden du forudsætter, han ikke har sagt, hvad Kirken vidner?" (US IV, 633f.). Og Loke er lige så vedholdende i sin bestræbelse på at knytte Kristus sammen med fornuften: "Ordenlig oplyste Folk maatte nødvendig indsee, at skal Kirkens Christus være Lyset og Sandheden, altsaa Fornuften selv, maa han ogsaa nødvendig sammensmelte med Fornuftens eget Ideal, og at man derfor ret godt kan sammenfatte Begge i eet Begreb" (634). Præsten insisterer ved endnu engang at konfrontere Loke med et enten-eller:

Eet af To altsaa: enten maa du indrømme, at Alt, hvad Christus i Kirken vidner og lover, virkelig kan medføre Sandhed, og være Fornuftens Ideal værdigt, eller du maa tilstaae, at baade du og dit Fornuft-Ideal staaer aldeles fjendtlig mod Kirkens Christus, der umuelig kan være noget Andet, end hvad Kirken udgiver ham for! (US IV, 634).

Det er påfaldende, at vi i denne sidste formulering pludselig har to opfattelser af "Fornuftens Ideal" stående over for hinanden; men desværre bliver forskellen ikke uddybet. 


\section{Bibelsyn}

Mod slutningen af dialogen får spørgsmålet om bibelsyn og Bibelens status i kirken en vigtig plads. Præsten taler om "os strænge lutherske Theologer, som paastaae, det er klogest at tage og troe Bibelen paa Ordet" (US IV, 629). Formuleringen antyder, at det ikke forholder sig helt så enkelt, at Grundtvig med den "mageløse opdagelse" slet og ret opgiver sit tidligere bibelsyn. Loke slutter heraf følgende: Hvis kirken ikke vil tilstå, at "hun lige fra Barns-Been har snakket hen i Taaget, maa hun jo dog forsvare Alt, hvad der staaer i Bibelen, som et ufeilbart Guds Ord, indblæst af den Hellig-Aand selv" (US IV, 636). Men præsten spørger tilbage: "med hvilke Ord udtrykker Kirken sig egenlig om Skriften?" (US IV, 636) - underforstået: det gør den slet ikke. Loke stiller sig dog ikke tilfreds med dette svar og fortsætter:

I raaber altsaa fra Prædikestolen hvert Øieblik: der staaer skrevet, uden enten selv at troe paa Skriften, eller fordre den Tro af Menigheden! Det, maa jeg bekjende, er en Adfærd, som ret mærkelig [tydeligt] characteriserer Strængheden i din mageløse Præste-Logik! (US IV, 637).

I stedet for at svare direkte på dette vælger præsten at henvise til ordinationen og prcesteløftet, "hvad jo, hos cerlige Mænd, forudsætter den Tro, at Guds Ord virkelig findes i Skrifterne (...) eller kan du maaskee bevise, at Guds Ord ikke findes i de Prophetiske og Apostoliske Skrifter!" (US IV, 637). Et sådant bevis vil Loke forståeligt nok ikke indlade sig på; han forsøger i stedet at holde fast i sin kritiske pointe: "Lutter Ordkløveri, slet ikke Andet; thi det Hele løber jo dog ud paa, at naar I sige: der staaer skrevet, skal hele Menigheden tænke, det er vor Herre selv, der taler; og ham maae de jo dog, om de vil blive salige, troe uindskrænket!" (US IV, 637).

Mod slutningen af dialogen taber Loke opmærksomheden og er ved at falde i søvn "over din ligesaa kjedsommelige som indbildske Præke-Tone, at jeg ikke længer veed, hvad det egenlig er, du vrævler om" (US IV, 640). Umiddelbart efter, i præstens replik, bindes sløjfen så fint tilbage til den indledende kamp om forholdet mellem sandhed og fornuft (som vi husker, forsøgte Loke jo forgæves at forkaste kristendommen som stridende mod fornuften): "Du veed da altsaa ikke heller, hvad det egenlig var, du $i$ Sandheds Navn vilde nedrive hos Kirken, og da jeg agter det for høist ubetydeligt, hvad du kan sige og gjøre mod Christi Kirke i dit eget, i din egen ubegribelige Fornufts og sprænglærde Hjernes Navn, saa dimitterer jeg dig" (US IV, 640).

Loke er dog i mellemtiden vågnet så tilstrækkeligt op, at han kan komme med følgende afskedssalut: "Jeg er inderlig glad ved at kunne afbryde en af de flaueste og ærgerligste Samtaler, mit Kald, som Lysets og Fornuftens Talsmand, nødte mig til at føre med ligesaa lumske som 
tykhovdede, forbistrede Præster, uden at du, med mindste Skin, skal kunne sige, jeg stjal mig bort, eller tav beskjæmmet" (US IV, 640). Det går dog naturligvis ikke anderledes, end at præsten făr det sidste ord:

[S]aa blev det jo dog lige vist, at du, indtil videre, fandt dig uskikket til at bevise din uforskammede Paastand, at den historisk-christelige Kirke farer med Løgn, og kun for at faae det gjort indlysende, var det naturligviis, jeg indlod mig i en Samtale (...) Gaae derfor nu kun hjem og læg dig (...), da din Mund har gjort mig al den Tjeneste, jeg forlanger af den; thi det var, hvad skedt er, at den, uden nogen udvortes Aarsag, gik i Baglaas af sig selv, da den skulde svare til sin Paastand, og bevise, at Kirke-Stormen var Andet end et tomt Munds-Veir, for hvilket vel et Bog-Blad kan vende sig, men ingen Mure styrter! (US IV, 640f.).

\section{Efter dialogen}

Ved starten af næste stykke i Theologisk Maanedsskrift (april 1827) indleder Grundtvig med en form for selvransagelse. Han ser tilbage på "de forrige Stykker af denne Betragtning" (= alt det forudgående?) og har indset, at "det er just ikke i den bedste Orden, skjøndt det var min Bestræbelse, saa klart som mueligt, at oplyse den theologiske Vildfarelse, der, uden et besynderligt [scerligt] Guds Forsyn, maatte voldt den christelige Kirkes Undergang, og truer endnu, hvor den findes, Troens Liv: den nedarvede Vildfarelse nemlig, at ikke Kirkens levende Troes-Bekjendelse, men Skriftens Bogstav var Christendommens første Kundskabs-Kilde" (US IV, 641). Med andre ord: han slår i drastiske vendinger fast, hvor vigtig hans nyvundne kirkelige anskuelse er. Derefter beklager han manglen på orden i fremstillingen - som vi vel kan tillade os at tilføje ikke kun gælder for dialogen mellem præsten og Loke:

[T]hi vel veed jeg, at Sandhed, ved at udvikle sig i en stræng TankeFølge, hardtad aftvinger Forstanden sit Bifald, men jeg veed ogsaa, at fattes Livet i en saadan Udvikling, da er det Bifald, den aftvinger, dødt og magtesløst, og mig er det ikke givet at forene stræng Orden med Livet, men kun bagefter historisk at opfatte og angive, hvorledes man i Tankerne maa ordne dets Momenter, naar man vil klare sig den dunkle Sammenhæng. Mine Læsere maa derfor vænne sig til den Særhed hos mig (...). Netop fordi det poetiske og videnskabelige Element hos mig er venlig og vel forligte om Materien, strides de bestandig om Formen, og naar jeg selv vil lægge mig derimellem, ophører vel Striden, men naturligviis ogsaa den levende Vexel-Virkning, saa jeg, som her, bliver min egen Historie-Skriver, hvad Skribenten immer taber, og Læseren kun engang imellem vinder ved (US IV, 641f.).

På de følgende sider taler Grundtvig om sin kristelige tro og bekender, at "med min Overbeviisning om Fæderne-Troens Ægthed og Herlig- 
hed er kun skedt den Forandring, at Den har mærkelig vundet saavel i Fasthed, som i Liv og Klarhed" (US IV, 642). Og herefter beskriver han så overgangen fra skriftprincippet til trosbekendelsen ved dåben, altså den mageløse opdagelse, i en slags omvendelses-terminologi, nemlig som et før til forskel fra et $n u$. Før, siger han, antog jeg med fædrene, at man måtte bevise troens ægthed ud fra Skriften, "men disse mine Tanker har jeg aldeles forandret"; og det vil han på grund af sagens særlige vigtighed fremlægge grundene til her, "da det ingenlunde er ligegyldigt, om vi forsvare vor Tro godt eller slet, og endnu mindre, enten vi bygge vore Overbeviisning om Dens agte Christelighed paa en vaklende eller paa en urokkelig, paa en død eller paa en levende Grundvold" (US IV, 642). Man ser altså her, at det for Grundtvig er afgørende at få troen baseret på en urokkelig grundvold. At det især er bibelkritikken og de deraf følgende storme, som grundvolden skal kunne holde stand over for, bliver klart af det umiddelbart følgende, hvor Grundtvig taler om, hvordan "vor Fædrene-Troes ægte Christelighed (...) i vore Dage er blevet hardt anfægtet, selv af mange, der kalde sig christelige Bisper, Præster og Professorer" (US IV, 643).

Man vil vanskeligt kunne komme uden om, at denne sidste klage minder påfaldende om den kritik, der i vore dage lyder fra den kirkelige højrefløj. Forskellen er dog, at Grundtvig har trukket sig fra kampen om Bibelens rette udlægning og i stedet valgt, hvad man kunne kalde for en less is more-strategi: lad os finde noget, der er så lidt som muligt, men samtidig er fælles for alle kristne: trosbekendelsen, hvis brug ved dåben samtidig viser, at den er et optagelsesvilkår for menighedens trosfællesskab. Trosbekendelsen er, som han i vores tekstsammenhæng udtrykker det, "jo et fuldgyldigt Vidnesbyrd om, hvad alle de skal troe, der vil være Christne", og i kirken kan ingen være, "som aabenbar fornægter og forkaster sin Daabs-Pagt" (US IV, 643). ${ }^{18}$ Grundtvig har altså her samtidig fået sat skellet: han ved nu, hvordan han kan skille fărene ("Christne") fra bukkene ("UChristne").

$N u$, siger han derfor, "kan vi da rolig overlade til Enhver: hvilken Forsikkring om den ægte Christendom de helst vil troe, enten den hele christelige Kirkes og Menigheds høitidelige Vidnesbyrd ved Daaben gjennem mange Aarhundreder, eller nogle fra deres Daabs-Pagt affaldne Boglærdes Paastand, som ovenikjøbet vil indbilde os, at Christendommen var fra Begyndelsen det rene Hedenskab" (US IV, 643). Denne nyvundne ro og sikkerhed ledsages desuden af to yderligere gevinster: For det første lærer trosbekendelsen os "tillige at skille imellem den christelige Tro, som vi har tilfælles med alle dem, der har

${ }^{18}$ Jf. Grundtvigs betoning af, at der til dåbspagten er knyttet en "TroskabsEed" (US IV, 537). 
været Christne før vi (...) og vor christelige Oplysning, der rimeligviis kan være større end vore Forfædres" (US IV, 643; kursiveret her). Og for det andet betoner Grundtvig den fordel, at nu "behøver da Menigheden ikke at troe blindt paa sine Præster, men kan bedømme deres Tale om, hvad der staaer i Skriften, efter Troens Regel [regula fidei]" (US IV, 643f.).

\section{Afsluttende vurdering}

Det er den nyvundne opdagelse (1825) af trosbekendelsen ved dåben, der dominerer Grundtvigs apologetiske dialog, ligesom man flere steder hører et ekko af Kirkens Gienmole. Det er (på nær spørgsmålene om bibelsyn og nadver) trosbekendelsens enkelte led, der udgør temaerne for den "videnskabelige Samtale". Præsten, Grundtvigs talerør, er styrende i samtalen; det er ham, der primært bestemmer, hvad der skal tales om. Særligt bør her fremhæves, at det er præsten, der får dirigeret dialogen i de to - for Grundtvigs teologiske dagsorden essentielle - retninger: først fra fornuft til sandhed, og dernæst til en koncentration om trosbekendelsen ved dåben som det eneste, kirken har at skulle forsvare. Desuden er det kendetegnende, at det er Loke, som med jævne mellemrum bliver udfordret med hensyn til, om han mon kan bevise, at den og den påstand ikke kan være mulig sandhed. I den forstand kan man sige, at præsten hele vejen igennem er i angriberens rolle (angreb er som bekendt ofte det bedste forsvar). I lyset af den i grunden overraskende beskedne sandhedsfordring, Grundtvig stiller på den kristne tros vegne, nemlig at den ikke lader sig "afbevise" og derfor kan være mulig sandhed, bør det således noteres, at han - trods sin til tider voldsomme retorik - indskrænker sig til en defensiv applikation af modsigelsens grundsætning. Og selv i denne funktion kan det være svært at indse, at modsigelsens grundsætning er ham til megen hjælp. At troens (dvs: trosbekendelsens) udsagn muligvis kan være sande, eller at de ikke kan "afbevises", vil næppe mange bestride. $^{19}$

Hertil kommer, at der knytter sig en del uklarhed og uforløste spændinger til Grundtvigs brug af modsigelsens grundsætning. Det ligger i sagens natur, at den indikerer en skarp modsætning, et uforsonligt enten-eller, som også præger store dele af Grundtvigs retorik. Ved nærmere eftersyn passer dette enten-eller dog ikke så godt til Grundtvigs egentlige dualisme, som - netop fordi den er teologisk forankret er en hierarkisk dualisme forstået på den måde, at modsætningerne livdød, lys-mørke, sandhed-løgn, etc. ikke er fuldstændig ligestillede.

${ }^{19}$ Det bør i denne forbindelse tilføjes, at Grundtvig flere steder indikerer, at troens endelige verifikation er eskatologisk. 
Snarere kan man sige, at de er tænkt à la Augustin som en privatio: mørket er fravær af lys, og løgnen snylter på sandheden. Til trods for det hos Grundtvig markante kamp-motiv, der unægtelig trækker i dualistisk retning, forbliver der således ikke desto mindre en uforløst spænding mellem modsigelsens grundsætning som logisk-filosofisk værktøj, - og så den teologisk-ontologiske opfattelse, hvor der på grund af Guds gode skaberværk (og naturligvis for at undgå en dualisme $\mathrm{i}$ selve gudsbegrebet) er tale om et værdibaseret hierarki funderet i tanken om det onde/Djævelen, som nok er en realitet, der virker og må bekæmpes, men trods alt noget afledt, noget, der er blevet til ved et fald.

Dialogen undgår derfor heller ikke helt at få karakter af en skinkamp, for den er i Grundtvigs optik afgjort på forhånd. Når han ifører sig kappen som filosofisk logiker, er det derfor i en vis forstand på skrømt, eller rettere: som et apologetisk værktøj, der skal tjene en større og højere sag. Man kan også sige det på den måde, at modsigelsens grundsætning primært er beregnet på modstanderne. For Grundtvig selv stiller det sig anderledes, for han ved allerede både, hvor sandheden er at finde - og hvad den går ud på: Gud er Sandhed, Kristus er Sandhed, og Helligånden er "Sandheds Aand". Endvidere, og måske især, er der grund til at antyde en mere almen filosofisk indvending: Som formallogisk princip kan modsigelsens grundsætning kun finde anvendelse på domme, altså på sproglige udsagn om virkeligheden; men er trosudsagn (in casu: trosbekendelsens led) "domme" i denne forstand? Næppe, eller rettere: heldigvis ikke.

Det kan således konstateres, at der allerede immanent, altså $\mathrm{i}$ Grundtvigs egne tekster, er uklarheder i det apologetiske projekts kerneområder, som han åbenbart ikke selv ser, fordi han nærer en overdreven tillid til modsigelsens grundsætning. På den baggrund kunne man derfor sige, at det i det mindste tjener Grundtvig til ære, at han erkender, at man ved hjælp af modsigelsens grundsætning ikke kan komme længere end til det noget skuffende og defensive resultat, at den kristne tro kan være mulig sandhed. Men selv dette er jo en tilsnigelse, for i forhold til et formallogisk sandhedsbegreb er trosudsagn jo netop ikke sandhedskandidater - og kan og bør ikke være det.

Så hvad vil Grundtvig dog med modsigelsens grundsætning? Jo, for det første har vi set, at han kan benytte den som et middel til at afvaerge eller afparere angreb. Han har netop den idé, at modsigelsens grundsætning fungerer som en boomerang, der gør, at kristendommens modstandere eller angribere făr deres egne argumenter smidt $i$ hovedet igen, så deres frække munde af sig selv går i baglås. For det andet - og teologisk set ulige vigtigere - har vi ovenfor set Grundtvigs indrømmelse af, at han ene og alene fører den strid, som han i øvrigt anser for 
unyttig, af hensyn til fastholdelsen af gudstankens strenghed: Gud er Sandheds Gud, der ikke kan modsige sig selv. I denne forstand (men også kun i denne) giver det mening med Høirup at udnævne modsigelsens grundsætning til Grundtvigs teologiske aksiom (jf. Høirup 1949, især konklusionen side 369-398).

Er Grundtvigs apologetiske dialog mellem præsten og Loke så vellykket? Derpå kan der svares bekræftende i forhold til formålet med, af hensyn til læserne, at få skabt mere liv i fremstillingen af kristendommens sandhed. Anlægger man derimod den synsvinkel, at Grundtvig har lavet dialogen for sin egen skyld for at kunne demonstrere, hvor effektivt et våben modsigelsens grundsætning er, og hvor store fordele der er forbundet med at være kommet fra den evindelige strid om Skriften og over i trosbekendelsens trygge havn, så vil det være min vurdering, at dialogen er en fiasko. Det skal dog understreges, at der hermed ikke er taget stilling til Grundtvigs apologetiske bestræbelser in toto, for det ville forudsætte en mere omfattende analyse af blandt andet hans samtids-, fornufts- og filosofikritik.

Hvis man ikke desto mindre rejser det relevante spørgsmål om, hvad vi $i$ dag kan stille op med Grundtvigs apologetiske brug af modsigelsens grundsætning, ses ingen anden udvej, end at vi én gang for alle erkender, at alt, hvad der hos Grundtvig findes af modsigelsens grundsætning og tale om "soleklare Beviser" (fx US IV, 495, 571 og 591), er vildledende, uforsvarligt og udtryk for, hvad man kunne kalde for en objektivistisk selv-misforståelse. Kort sagt: det står for en religionsfilosofisk betragtning ikke til at redde. Og det standser ikke her, for så vidt som selv-misforståelsen også kan udstrækkes til at gælde "den mageløse opdagelse", hvor en analogi til Columbus unægtelig trænger sig på: Columbus mente som bekendt at have fundet Indien, men opdagede i virkeligheden Amerika. Grundtvig mente at have fundet en urokkelig grundvold mod troens modstandere og fjender, men i virkeligheden havde han med den kirkelige anskuelse opdaget menigheden og det gudstjenestefejrende fællesskab. Sådan som hans Sang-Vark da også vidner om. ${ }^{20}$

\section{Forkortelser}

US I-X: Holger Begtrup (udg.) (1904-09), Nik. Fred. Sev. Grundtvigs Udvalgte Skrifter, I-X, København.

$V U$ I-X: Christensen, Georg og Koch, Hal (udg.) (1940-49), N. F. S. Grundtvig. Voerker i Udvalg, I-X, København.

${ }^{20}$ For en uddybning og perspektivering af dette synspunkt, se Dokka 2011, der behandler Grundtvig-receptionen i 1920'ernes norske teologi, specielt hos Bjarne Skard. 


\section{Litteraturliste}

\section{Voerker af Grundtvig}

Christensen, Georg og Koch, Hal (udg.) (1940-49), N. F. S. Grundtvig. Verker i Udvalg, I-X, København.

Begtrup, Holger (udg.) (1904-09), Nik. Fred. Sev. Grundtvigs Udvalgte Skrifter, I-X, København.

Grundtvig, N. F. S. (1983), Om Mennesket $i$ Verden (udgivet i 200-året for Grundtvigs fødsel og forsynet med indledning og noter ved K. B. Gjesing). Herning.

\section{Voerker af andre forfattere}

Dokka, Trond Skard (2011), "En maken 'mageløs opdagelse'? Bjarne Skard, N.F.S. Grundtvig og mellomkrigstidas nye kirkelighet" i H. Elstad \& T. Rasmussen (red.), Teologi og modernitet. Universitetsteologien $i$ det 20. hundreåret, Oslo, 207-234.

Dorrien, Gary (2001), The Making of American Liberal Theology: Imagining Progressive Religion, 1805-1900, Louisville.

Glebe-Møller, Jens (2011), "Grundtvig og rationalisterne", Grundtvig-Studier 2011, København, 81-92.

Høirup, Henning (1949), Grundtvigs Syn paa Tro og Erkendelse, København. Kelstrup, Erik (2000), "Grundtvigs anvendelse af modsigelsens grundsætning i 'Kirkens Gienmæle' - filosofisk belyst', Grundtvig-Studier 2000, København, 126-153.

Kelstrup, Erik (2003), Sandhedsbegrebet hos N. F. S. Grundtvig kritisk vurderet ud fra sandhedsteorier $i$ det 20'ende århundredes analytiske og hermeneutiske filosofi, utr. ph.d.-afhandling, Aarhus Universitet, katalogiseret og kan udlånes via Statsbiblioteket (nu: Aarhus University Library), www.statsbiblioteket.dk.

Rasmussen, Jens (1998), "N. F. S. Grundtvig og 'Rationalisterne' i årene 1825-32. Synspunkter og udvikling”, Grundtvig-Studier 1998, København, 95-119 